ROCZNIKI HUMANISTYCZNE

Volume 66, issue $2-2018$

SELECTED PAPERS IN ENGLISH

DOI: http://dx.doi.org/10.18290/rh.2018.66.2-4se

PAWE€ KRAS

\title{
PUBLIC PENANCE OF HERETICS: ITS FORMS AND FUNCTIONS*
}

In the Middle Ages, heresy (haeretica pravitas) was treated as an error in faith (error fidei), contrary to the teaching of the Church, or a grave sin (grave peccatum), and at the same time one of the most serious contraventions of canon law (crimen). In a world where faith and religious values deeply pervaded all aspects of social life, heresy was also a serious breach of social order (crimen publicum). ${ }^{1}$ It belonged to bishops, and from the $1230 \mathrm{~s}$ to papal inquisitors too, to combat heresy and its followers in order to defend the purity of the doctrine of the faith and unity of the Church. Their main task was to seek the return of heretics to the Church by renouncing errors and making an orthodox confession of faith. As Bernard Gui, an inquisitor of Toulouse, wrote in a manual for inquisitors Practica inquisitionis haereticae pravitatis, the aim of the Inquisition was to destroy heresy either by returning heretics to the Church (conversio) or by their extermination (exterminatio). ${ }^{2}$ At the same time, Gui emphasized that the inquisitor should

Dr Hab. Pawee Kras - an associate professor at the John Paul II Catholic University of Lublin (KUL), head of the Department of Jagiellonian Europe Culture and History, director of the Institute of History of KUL in 2010-2013; e-mail: palks@ @ul.pl

The Polish version of the article was published in Roczniki Humanistyczne vol. 59, issue 2 (2011).

* The text is an extension of a paper presented at the conference entitled "Medieval Man in the face of the sacrum. Ritual, gesture, prayer," organized by the Institute of History of Siedlce University of Natural Sciences and Humanities Academy in Drohiczyn on 13 September 2008.

Norman Conn, Europe's Inner Demons. The Demonization of Christians in Medieval Christendom (London: Pimlico, 1993²), 35-78; Grado G. MerLo, "Membra diaboli, demoni ed eretici medievali," Nuova Rivista Storica 72, nos. 5-6 (1988): 583-598; Alexander PATSCHOvsKY, "Der Ketzer als Teufeldiener," in Papstum, Kirche und Recht im Mittelalter. Festschrift H. Fuhrmann zum 65. Geburtstag, edited by Hubert Mordek (Tübingen: Max Niemeyer Verlag, 1991), 317-334.

${ }^{2}$ Bernard GuI, Practica inquisitionis haereticae pravitatis, edited by Célestin C. Douais (Paris, 1886 [henceforth abbreviated as Practica]), 217-218. 
do all in his power to induce a heretic to abandon sinful life (correctio) and return to the Catholic faith (conversio). Using suggestive imagery, he compared a heretic who abandons heresy to a prodigal son returning to his father's house (Luke 15:11-32). Just as the merciful father in Jesus parable rejoiced at the return of the son whom he had considered dead, so should the Church rejoice at the conversion of every heretic. ${ }^{3}$

The full reintegration of the heretic into the Church called for long and severe penance, which served to purify the heart and mind of sins as well as compensating God and the Church for the wrongdoing. Elaborating the doctrine of the sacrament of penance developed in the writings of the Church Fathers, medieval theologians and canonists regarded penance as a remedy (medicina) that healed wounds created in the soul of the heretic as a consequence of his deviation from the truth of God. In eschatological terms, strict and conscientious repentance gave hope of saving the soul from eternal condemnation, and the expiation for sins, which began in mortality, was to be continued in Purgatory. ${ }^{4}$

Penance imposed on heretics was either private or public. The first kind consisted of various religious practices: prayers, services, fasting, almsgiving as well as flogging. Unlike private penance, giving the sinner a great amount of discretion, public repentance was carried out openly and solemnly, with the participation of the entire parish community. It was connected with the need for the penitent to wear a special robe, which augmented his status (ordo poenitentium). ${ }^{5}$ This form of public compensation for sins stemmed from the Judaic tradition. Its traces can be found in the Old Testament, where particularly grave violations of God's law required public penance. The oldest description of such penance can be found in the First Book of Kings, which describes the penance of the Israeli King Ahab (ca. $874-853 \mathrm{BC}$ ). On hearing about the death of Nebot, who had been stoned to

\footnotetext{
${ }^{3}$ Idem, 60, 100.

${ }^{4}$ Jacques Le Goff, Narodziny czyśćca, translated by Krzysztof Kocjan (Warszawa: Państwowy Instytut Wydawniczy, 1997), 243-248 (here p. 244); Pierre Michaud-Quantin, Sommes de casuistiques et manuels de confession au Moyen Age (XII-XVI siècle) (Éditions Nauwelaerts; Lille: Librairie Giard; Montreal: Librairie Dominicaine, 1962), 19-20. Analecta mediaevalia Namurciensia 13; Mary C. Mansfield, The Humiliation of Sinners. Public Penance in Thirteenth Century France (Ithaca-London: Cornell University Press, 1995), 48-49.

${ }^{5}$ John H. ARNOLD, Inquisition and Power. Catharism and the Confessing Subject in Medieval Languedoc (Philadelphia: University of Pennsylvania Press, 2001), 62-63; Christine E. CALDwell, "Dominican Inquisitors as 'Doctors of Souls': The Spiritual Discipline of Inquisition, 1231-1331," Heresis 40 (2004): 32-33; IDEM, Righteous Persecution. Inquisition Dominicans and Christianity in the Middle Ages (Philadelphia: University of Pennsylvania Press, 2009), 169-177.
} 
death on a false accusation, Ahab "tore his robe, put on sackclothes and fasted. He also went to sleep in sackcloth and walked around humbly" (1 Kings 21:27). ${ }^{6}$

The form and course of public penance developed in Antiquity. In the Church's teaching on the sacrament of penance, which was being born in Antiquity, the conviction developed that no one who sincerely confessed his sins could be denied the grace of forgiveness and reconciliation. ${ }^{7}$

In the period of early Christianity, canonical penance was imposed by the bishop for grave violations of God's commandments and church discipline. Throughout the whole period of penance, the penitent would wear a penitential robe and was subject to a specific discipline of ascetic practices. Although he participated in the religious life of his community, he could not receive the sacraments. During religious services he would stand in a special place, usually at the entrance to the temple. ${ }^{8}$

The forms and functions of penance were examined at length by the saints Ambrosius, Augustine, Leo the Great and Caesarius of Arles. The evolution of forms of penance was strongly influenced by the distinction between venial and grave sins developed in the second and third centuries. The former, resulting from human weakness, could only be repented through prayer, fasting and almsgiving. The latter, stemming from ill will (peccata malitiae),

\footnotetext{
${ }^{6}$ Nicolau Eymerich and Francisco PeÑA, Le manuel des inquisiteurs, edited by Louis SalaMolins (Paris-La Haye: Mouton, 1973), 171. Le savoir historique 8 [henceforth abbreviated as Manuel].

${ }^{7}$ In the early fifth century, Pope Celestine castigated those who refused to administer the sacrament of reconciliation to sinners even though they penitently confessed their guilt at the hour of death. CELESTINE, "Listy," in Antologia patrystyczna, edited by Andrzej Bober (Kraków: Wydawnictwo WAM, 1965), 277.

${ }^{8}$ In the last half-century, the issue of medieval penitential liturgy has become a subject of intensive research by theologians, canonists and liturgists. See, among others, Pierre Marie Gy, "Histoire liturgique du sacrament de pénitence," La Maison-Dieu. Revue de pastorale liturgique 56 (1958), 5-21, and Cyrille Vogel, Le pécheur et la pénitence dans l'Eglise ancienne (Paris, 1966); IDEM, Le pécheur et la pénitence au Moyen Âge (Paris: Éditions du Cerf, 1969) supplemented and re-edited Italian version: Cyrille Vogel, Il peccatore e la penitenza nel medioevo, edited by Clara Achille Cesarini (Torino: Editrice Elle Di Ci, 1988). Of the newer works, it is worth looking at Mary C. MANSFIELD, The Humilation of Sinners. Public Penance in Thirteenth Century France (Ithaca-London: Cornell University Press, 1995); Confession in the Middle Ages, edited by Peter Biller and Alistair J. Minnis (Woodbridge, Suffolk, Rochester, NY: York Medieval Press, 1998). York Studies in Medieval Theology 2. A systematic discussion of the evolution of the penitential liturgy of the ancient and medieval Church in Polish includes the following works: Bogusław NAdOLSKI, Sakramenty, sakramentalia, błogosławieństwa (Poznań: Wydawnictwo Pallotinum, 1992), 81-109. Vol. 3 of Liturgika; and Marian PASTUSZKO. Sakrament pokuty i pojednania (Kielce: Wydawnictwo Jedność, 1999), in particular 11-28.
} 
cardinal sins (peccata capitalia) required public penance. Grave sins included denial of faith, idolatry, adultery, murder, and other serious violations of God's law. According to the Fathers of the Church, these sins separated the perpetrators from communion with the body of Christ, and they had to compensate them through severe penance. All grave sins, both hidden and public, required canonical penance. Unlike private penance, which could be repeated, canonical penance was imposed only once. The principle of the uniqueness of canonical penance, formulated in the second half of the second century, (Hermas, Tertullian), was adopted by the ancient Church. Underlining the importance of baptism, through which sins are forgiven, Tertullian treated canonical penance as something special and one-off. ${ }^{9}$ Writing nearly two centuries later, Ambrose of Milan admitted that "just as there is one baptism, there is one penance, but this takes place in public. We should also repent for our daily sins, but this penance is due for venial sins and the former is for grave sins" (Epistola 41,12$).^{10}$

In Late Antiquity, canonical penance took the form of a specific liturgical rite, the purpose of which was to publicly compensate God and the Church for a grave sin. On the one hand, it served to appease God for violating His law and, on the other hand, to restore the social equilibrium disrupted by the misdemeanour. ${ }^{11}$ The repenting sinner who was part of a separate group of

\footnotetext{
${ }^{9}$ Tertullianus Quintus SePtimus Florens. “De poenitentia.” Patrologiae Latinae cursus completus, vol. 1, edited by Jacques Paul Migne. (Parisiis, 1844) [henceforth abbreviated as PL], coll. 1243 B-1244 A: "Hujus igitur poenitentiae secundae et unius, quanto in arcto negotium est, tanto operosior probatio, ut non sola conscientia proferatur, sed aliquo etiam actu administretur. Is actus, qui magis graeco vocabulo exprimitur et frequentatur, Exomologesis est, qua delictum Domino nostrum confitemur: non quidem ut ignaro, sed quatenus satisfactio confessione disponitur, confessione poenitentia nascitur, poenitentia Deus mitigatur. Itaque Exomologesis prosternendi et humilificandi hominis disciplina est, conversationem injungens misericordiae illicem; de ipso quoque habitu atque victu mandat, sacco et cineri incubare corpus sordibus obscurare, animum moeroribus dejicere, illa quae peccavit tristi tractatione mutare; caeterum pastum et potum pura nosse, non ventris scilicet, sed animae caussa: plerumque vero jejuniis preces alere, ingemiscere, lacrymari, et mugire dies noctesque ad Dominum Deum tuum, presbyteris advolvi, et caris Dei adgeniculari, omnibus fratribus legationes deprecationis suae injungere." Polish translation in Jan SŁoмKA, editor, Chrzest i pokuta w Kościele starożytnym. Antologia tekstów I-III w. (Kraków: Wydawnictwo “M,” 2004), 179-180. Biblioteka Ojców Kościoła 24.

${ }^{10}$ Ambrosius MediolanENSIS, "Epistolae," PL 16, coll. 1164, http://www.documentacatholica omnia.eu/02m/0339-0397,_Ambrosius,_Epistolae_Prima_Classis,_MLT.pdf: Ecclesia autem et aquam habet et lacrymas habet: aquam baptismatis, lacrymas poenitentiae.

${ }^{11}$ John Norman Davidson Kelly, Early Christian Doctrines (London: Adam \& Charles Black, 1977 [reprint 1997]), 216- 219; Stanisław CzERwIK, “Zarys dziejów pokutnej praktyki Kościoła,” in Sakrament pokuty. Teologia-Liturgia-Pismo Święte, by Alfons Skowronek, Stanisław Czerwik, Michał Czajkowski (Katowice: Księgarnia Św. Jacka, 1980), 147-152.
} 
penitents-ordo poenitentium. During religious services, its members were in a separate place, usually in front of the entrance to the church or in the vestibule. The penitential status was emphasized by the person's appearance (a cilice and shaved head sprinkled with ash). ${ }^{12}$

In both the ancient and medieval Church, the length of penance was determined by the bishop, who adapted it to the kind of sins committed and the attitude of the sinner. The canons of the fourth-century synods prescribed that penance be long-lasting or even life-long. The Synod of Elvira in 306 A.D. introduced ten-year-long penance applicable to heretics who acknowledged their sins and wished to return to the Catholic Church (c 22). ${ }^{13}$ Eight years later, the synod in Ancyra defined in detail the length and form of canonical penance according to the nature of the offence. Penitents were divided into those who listened and those who prostrated (cc. $4-10,16){ }^{14}$

The medieval penitential liturgy took over the forms and rites that had been formed in the ancient Church. In Gaul, a penitent was required to cut his hair. In Spain, penitents had to wear a long beard and neglected hair as a sign of the many sins committed. Detailed regulations regarding public penance and reconciliation were developed at the Synod of Agde in 506. Penance was to begin with a priest putting the hands on the penitent and donning of a penitential sack. The change of apparel was an external sign of accepting the penance and at the same time a symbol of the spiritual transformation of the sinner (c. 15). ${ }^{15}$

St. Caesarius of Arles devoted much attention to public penance and the principles of reconciling sinners with the Church. His sermons shed light

\footnotetext{
${ }^{12}$ Hermias Sozomenus, who wrote in the fifth century, discussed in detail the ritual of canonical penance in the Roman Christian community in Historia ecclesiastica (7.16). Sozomenos, Historia ecclesiastica. Kirchengeschichte, edited and translated by Günther Christian Hansen, vol. 3. (Turnhout: Brepols, 2004), 886-890. Fontes Christiani, 73; compare Friedrich Wilhelm WASSERSCHLEBEN, Die Bussordnungen der abendländischen Kirche (Halle: Verlag Graeger, 1851), 250 257 and 349-352; John Norman Davidson Kelly, Early Christian Doctrines, 219; Stanisław CZERWIK, "Zarys dziejów," 154-165.

${ }^{13}$ Arkadiusz BARON and Henryk PIETRAS, editors, Acta synodalia ab Anno 50 ad Annum 381 (Kraków: Wydawnictwo WAM, 2006), 53. Synodi et collectiones 1.

${ }^{14}$ Ibid., 63-66. See statutes of the Synod of Neo-Ceasarea (314-319), c. 5, ibid., p. 76.

${ }^{15}$ Joannes Dominicus MANSI, editor, Sacrorum conciliorum nova et amplissima collectio, vol. 8 (Florentiae, 1762 [reprint Paris-Leipzig, 1901]), col. 327: "Poenitentes, tempore quo poenitentiam petunt, impositionem manuum et cilicium super caput a sacerdote, sicut ubique constitutum est, consequantur. Si autem comas non deposuerint, aut vestimenta non mutaverint, abjiciantur et nisi digne poenituerint, non recipiantur. Juvenibus etiam poenitentia non facile committenda est propter aetatis fragilitatem. Viaticum tamen ordinibus in morte positis non negandum."
} 
on the ritual of reconciliation of sinners and their penance in early medieval Gaul. ${ }^{16}$

In the opinion of Caesarius, acceptance of penance was tantamount to exclusion of the sinner from the Church (Sermo 67, 2-3). ${ }^{17}$ Explaining the meaning of this ritual, Caesarius of Arles emphasized that the penitent excludes himself from the community because he does not feel worthy of participating in the sacrament of the Eucharist, that "one wants to be a stranger to the altar on earth in order to partake with a clear conscience in this altar which is in heaven." Wearing a cilice (cilicium) made of goat's hair was considered by Caesarius to be the symbol of the sinful nature of the penitents, which they attempted to change through severe penance $($ Sermo 67,1$){ }^{18}$ Thanks to penance involving praying, fasting, almsgiving, and pious deeds (visiting the sick, reconciling penitents, welcoming pilgrims), it was possible to purify the mind and heart, and simultaneously to compensate for the sins committed. Canonical penance, individually undertaken by the sinner no matter how, was expected to involve the entire community of the faithful, whose duty was to pray that God might forgive the penitents. ${ }^{19}$

The old Christian canonical penance disappeared during the sixth and seventh centuries, giving way to tariff penance. In penitential liturgy, the ritual of public reconciliation was abandoned. Penance imposed by the priest reflected the nature and number of sins committed, and its forms and duration was adapted to them. It was only in the Carolingian era $\left(8^{\text {th }}-9^{\text {th }}\right.$ centuries) that a return to the ancient penitential tradition took place, and the ritual of reconciliation and the corresponding public repentance was given

\footnotetext{
${ }^{16}$ More on the pastoral activity of St. Caesarius of z Arles see, among others, Ewa WIPSZYCKA, Kościót w świecie późnego antyku (Warszawa: Wydawnictwo Uniwersytetu Warszawskiego, 1994), 254-261.

17 "Et hoc adtendite, fratres, quod qui poenitentiam petit excommunicari supplicat. Denique, ubi acceperit poenitentiam, coopertus cilio foris eicitur. Idem enim se excommunicari rogat, quia ad percipiendam eucharistiam domini indignum esse se iudicati et propterea aliquandiu se ab isto altari alienum vult fieri, ut ad illud altare quod in caelo est mereatur cum secura conscientia pervenire." Germain Morin, editor, Sancti Caesarii Episcopi Arelatensis Sermones. Opera Omnia, vol. 1 (Turnhout: Brepols, 1953), 287. Corpus Christianorum seu nova Patrum collectio, Series latina 103.

18 "Et illud, fraters carissime, non otiose considerandum est, quod ille, de pilis caprarum texitur, et caprae peccatorum similitudinem habere videntur, ille qui paenitentiam accipit, non se agnum sed haedum publice profiteretur de rebus ipsis clamans et dicens: Videte me, omnes populi, et pro me misero omnes lacrimas pietatis efundite, et qualis sum foris, talem me intus esse agnosciti iam enim me nolo foris quasi iustum ostendere." Germain MoRIn, Sancti Caesarii Episcopi, 285; Antoni ŻUReK, Św. Cezary z Arles, 171.

${ }^{19}$ Ibidem.
} 
a new, extended form. Carolingian reformers restored the duty of public expiation for grave sins, which began during the reconciliation ceremony and continued for the prescribed penitential period. ${ }^{20}$ Repentance for grave public sins was public. Penance itself became a punishment in the strict sense, imposed for particularly disgraceful crimes which undermined social order. Where a misdeed or sin was directed against the community and its established system of values, penance served the purpose of public expiation and compensation for the harm caused.

The oldest descriptions of public penance (paenitentia publica) are preserved in the Gelasian Sacramentary (Ordo agentibus publicam paenitentiam). It prescribes that public repentance be imposed for grave sins. The period of penance started on Ash Wednesday at the beginning of Lent and lasted until Holy Thursday. On Ash Wednesday, the penitent's head, like other believers', was sprinkled with ash, and he himself would receive a cilice, which he had to wear throughout Lent. At the end of the service, the penitent was accompanied by a procession on his way to a separate room, where he remained until Thursday's liturgy. Throughout this time, the bishop and the entire community of believers prayed for him, asking God to forgive him and return him to the circle of believers. ${ }^{21}$

The revival of public penance occurred during the Carolingian period, when it was imposed on perpetrators of particularly serious crimes which undermined public order (crimina publica). Under canon law, such grave sins as murder of relatives, adultery, incest, and heresy called for expiation. As such, public penance became part of the penitentiary system, which was formed in the $12^{\text {th }}$ and $13^{\text {th }}$ centuries. According to Raymond of Penyafort, a papal penitentiary and editor of the Decretals of Gregory IX and author of

\footnotetext{
${ }^{20}$ Cyrille Vogel, Il peccatore, 14-20; Bolesław KosECKI, "Wyznanie grzechów w praktyce pokuty Kościoła na Zachodzie,” Ruch Biblijny i Liturgiczny 29 (1976), 75-76; Marian PASTUSZKo, Sakrament pokuty, 24-26; Paweł MATwIEJCZUK, "Pokuta kościelna w świetle penitencjałów z terenów Francji i Italii. Próba rekonstrukcji rzeczywistości historycznej," in Karolińscy pokutnicy i polskie średniowieczne czarownice. Konfrontacja doktryny chrześcijańskiej z życiem społeczeństwa średniowiecznego, edited by Maria Koczerska (Warszawa: Wydawnictwo DiG, 2007), 20-29. Fasciculi historii novi 7.

${ }^{21}$ Leo Cunibert Mohlberg, editor, Sacramentarium Gelasianum (Roma: Herder, 1960), nr 83; Henry Austin Wilson, editor, The Gelasian Sacramentary. Liber sacramentorum Romanae Ecclesiae (Oxford: Clarendon Press, 1894), 65: "Suscipis eum IIII feria mane in capite quadragesimae et cooperis eum cilicio, oras pro eo et inclaudis usque ad Caenam domini. Qui eodem die in gremio praesentatur ecclesiae, et prostrato eo omni corpore, in terram, dat orationem pontifex super eum ad reconciliandum in quinta feria Caenae domini, sicut ibi continetur." Compare Stanisław CZERWIK, "Zarys dziejów," 168.
} 
Summa de paenitentia, solemn public penance was to be meted out "pro crimine publico et vulgatissimo quod totam commoverit urbem." 22

In the $12^{\text {th }}$ century, solemn public penance (solemnis poenitentia publica) took the form of a carefully staged ritual of exclusion and reconciliation, the course of which is described in detail in synodal statutes and pontificals. ${ }^{23}$ It began on Ash Wednesday, when a penitent, dressed in a hairshirt, was symbolically excluded from the community of the faithful. Throughout Lent he participated in services, standing in front of the church door. His status was emphasized by his appearance (penitential sack, bare feet, a cane in hand). In this particular period of the liturgical year, public penance was of special importance. For every Christian, Lent was a time for reflection and penance for sins. Public penance conducted during the period leading to the celebration of the mystery of Christ's passion, death and resurrection was of exceptional importance. It served to make sinners realise the enormity of their transgressions, and at the same time to emphasize the greatness of the mercy shown to them by God and the Church. The time of exclusion and public penance ended on Holy Thursday, when the sinner participated in the rite of reconciliation and again became a member of the Church. ${ }^{24}$

In the inquisitorial penal system, solemn public penance had a prominent position in the process of reintegration of heretics with the Church. With it, the heretic publicly manifested his renunciation of past mistakes and his return to the Church. Converted heretics formed a separate group of penitents who were obliged to follow certain religious practices: regular participation in church services, public flogging, fasting and almsgiving. The appear-

\footnotetext{
${ }^{22}$ Raymond PENYAFORT, Summa de poenitentia et matrimonio, III, 34, § 3: "Solemnis poenitentia [...] debet imponi ab episcopo tantum [...] pro crimine publico et vulgatissimo quod totam commoverit urbem." Henry of Segusio spoke in a similar vein (Summa lib. 1, de officio archiepisco$p i$, no. 3): "[...] poenitentia solemnis imponi non debet nisi pro crimine publico et vulgatissimo quod totam urbem commoverit, puta pro homicidio, sacrilegio, incestu et consimilibus quae gravia sunt [...] et de omni peccato quod totam commoverit civitatem vel castrum." Quoted after Cyrille VoGEL, Le pèlerinage, 120, note 24.

${ }^{23}$ L. SCHIMDT ET AL., "Buße," in Theologische Realenzyklopädie, vol. 7 (Berlin: Verlag Walter de Gruyter, 1981), 473-496; Dorothea SATTLER, "Bußsakrament," in Lexikon für Teologie und Kirche, vol. 2, Freiburg: Herder-Verlag, 1994, coll. 845-853; Cyrille Vogel, "Buße, Westkirche. Bußdisziplin und Bußriten," in Lexikon des Mittelater, vol. 2, CD-ROM edition 2000, coll. 11311134 (see the literature section therein). See also Paweł KRAS, "Revocatio i reconciliatio: rytuały powrotu heretyka do Kościoła," in Rituàly, ceremonie a festivity ve střední a vychodni Europě 14. a 15. stoleti, edited by Martin Nodl and Frantisek Šmahel (Praha: Filosofia, 2009), 365-383.

${ }^{24}$ Odette Pontal, editor and translator. Les statuts synodaux français du XIII ${ }^{e}$ siècle, vol. 1 of Les statuts de Paris et le synodal de l'ouest (XIII siècle) (Paris, 1971), 101; for comparison, see statutes of William of Auvergne (Joannes Dominicus MANSI, vol. 22, col. 767).
} 
ance-penitential apparel, no headdress and bare feet-demonstrated their membership in this group. In Languedoc, and later in other parts of Europe, heretics returning to the Church had to wear signs of penance sewn on top of their clothing, most often crosses (crucesignati).

The rules of public penance for heretics returning to the Church were elaborated after the the Albigensian Crusade was over. After the Treaty of Paris of 1229, a systematic inquisitorial campaign was started in Languedoc. It became necessary to develop a comprehensive penitentiary system. Penance played an important role in the inquisitorial strategy to combat heresy, the form and duration of which were detailed in synodal statutes. Penance followed the liturgical ceremony of reconciliation, during which the heretic revoked the errors he had previously proclaimed (revocatio errorum, abiuratio), confessed the faith of the Catholic Church (confessio fidei) and-after the excommunication had been removed, was admitted into the sacramental community of the Church (absolutio et reconciliatio).

In the Dominican historiographical tradition, the image of the founder of the Order, St. Dominic, was already formed in the $13^{\text {th }}$ century as the first inquisitor (persecutor haereticorum), whose anti-heretical activity set the goals and tasks of later papal inquisitors. ${ }^{25}$ In addition to the expanding $13^{\text {th }}$ century set of legal regulations governing the functioning of the officii inquisitionis haereticae pravitatis, the rule of converting heretics verbo et exemplo, introduced by St. Dominic, was still applicable, at least for Dominican inquisitors. The method of persuading Cathars and Waldensians to abandon their errors and return to the Church through patient discussion and exchange of arguments (rationes et auctoritates) proved quite effective in the Languedoc region, where since 1206 Bishop Diego of Osma and St. Dominic carried out a preaching action against Cathars and Waldensians. ${ }^{26}$

${ }^{25}$ Christine Thouzellier, "L'inquisitio et saint Dominique," Annales du Midi 80 (1968): 121130; Marie-Humbert ViCAIRE, “'Persequutor hereticorum' ou les 'persecutions' de saint Dominique," Cahiers de Fanjeaux 6 (1971) : 75-83; IDEM, "Saint Dominique et les inquisiteurs," Annales du Midi 79 (1967): 173-194.

${ }^{26}$ The description of the activities of St. Dominic and Bl. Diego of Osma contains, among other things, the oldest historical work devoted to the origins of the Order of Preachers, originated by Jordan of Saxony. Jordanus DE SAXONIA, "Libellus de Principiis Ordinis Praedicatorum," in Monumenta historica sancti patris nostri Dominici, edited by Heribert Christian SCHEEBEN, no. 2 (Roma: Institutum historicum Fratrum Praedicatorum, 1935), 1-88. Monumenta Ordinis Fratrum Praedicatorum Historica 16; More on this in, for example, Marie-Humbert VicAIRE, Histoire de saint Dominique, vol. 1 (Paris: Le Cerf, second edition 1977), 183-240; compare Paweł KrAS, Ad abolendam diversarum haeresium pravitatem. System inkwizycyjny $w$ średniowiecznej Europie (Lublin: Wydawnictwo KUL, 2006), 143-147. 
There is a penitential document issued by St. Dominic for a Cathar perfectus, Pons Roger of Tréville. The future founder of the Order of Preachers imposed penance on the Cathar, who under the influence of his sermons, decided to abandon heresy and return to the Catholic Church. It says in the document that Pons had to subject himself to the ritual of public penance in his home town for three consecutive Sundays. As part of the penance, a procession led him from the city gate to the door of the parish church. All the way, he had to be naked to the waist and receive flogging from the pastor. ${ }^{27}$ After the public repentance was complete, he was obliged to follow a host of religious practices for the rest of his life, which involved daily prayers and regular participation in church services. Pons was totally forbidden to eat meat, eggs and cheese, with the exception of three holidays: Easter, Pentecost and Christmas. He also had to refrain from eating fish for three fortyday periods in a year. Three days a week he was not to eat fish, drink wine and olive oil. During the entire period of penance, he had to wear a religious habit with two small signs of the cross sewn onto his chest. As far as possible, he should attend Mass and say vespers every day. He was to say canonical prayers seven times a day, and Our Father ten times a day and twenty times a night. For the whole period of penance, Dominic ordered Pons to exercise complete sexual restraint. ${ }^{28}$ As Christine Caldwell aptly pointed out, the cycle of penitential practices imposed on Pons is reminiscent of the religious discipline which regulated the rhythm of life of the monastery members. While doing penance, the repentant sinner was in some way excluded from the laity. The regular prayers, fasting and participation in church services which he had to observe made him a member of the clergy. ${ }^{29}$ As in the case of consecrated persons, the liturgical calendar set the rhythm of his religious practices. Apart from sickness, nothing could justify his nonattendance even at one single service or unsaid prayer or fasting. Throughout the whole period he was additionally subjected to strict asceticism. Fasting and flagellation served to mortify the body and suppress the sinful tendencies of human nature. The status of a penitent, subjected to the discipline of monastic life, was emphasized by his clothing - a habit with the signs of the

\footnotetext{
${ }^{27}$ Marie-Humbert ViCAIRE, Histoire de saint Dominique, vol. 1, 300-301, 308.

${ }^{28}$ Monumenta historica sancti Dominici, edited by Vladimir Koudelka (Roma: Institutum historicum Fratrum Praedicatorum 1967), 16-18. Monumenta Ordinis Fratrum Praedicatorum Historica, 15; "Constantini Urbevertani Legenda sancti Dominici," in Monumenta historica sancti patris nostri Dominici, edited by Heribert Christian SCHEEBEN, no. 2 (Roma: Institutum historicum Fratrum Praedicatorum, 1935), 321-322.

${ }^{29}$ Christine E. CALDwell, "Dominican Inquisitors,” 23-40; IDEM, Righteous Persecution, 144-147.
} 
cross. Two decades later, the outfit with sewn-in crosses became the external symbol of a repentant heretic. ${ }^{30}$

By describing the penance of Pons of Tréville, this document was the only source presenting the confessional and penitentiary activities of St. Dominic in relation to heretics. It is impossible to clearly determine the impact of that source and possibly other similar documents on the system of penitential punishments introduced by the papal inquisitors. Analysis of penitential documents from the $13^{\text {th }}$ century or later (litterae poenitentiales), which have been preserved in the documentation of heresy trials, reveals a number of similarities both in terms of the form of penance imposed and its aims.

The penitential practice of St. Dominic involving converted heretics undoubtedly had a great influence on the first generation of papal inquisitors. Among the first Dominican inquisitors operating in Languedoc and appointed by Pope Gregory IX, there were two close collaborators of St. Dominic. One of them, Peter Sellan, was one of the oldest companions of St. Dominic. He was the first "Dominican" in every way and simultaneously the first benefactor of the newly created Order of Frriar Preachers. Sellan appeared beside St. Dominic in 1215, and from then on he remained in his immediate vicinity. In 1233, by the decision of the papal legate John Bernin, Archbishop of Vienne, he was appointed one of the papal inquisitors in Languedoc. ${ }^{31}$ The second companion of St. Dominic, Ferrer (Ferrier), who was a native of Catalonia, even before the papal nomination in 1233, had had inquisitorial functions in the service of Peter Amiel, Archbishop of Narbonne. Since then, until his dismissal in 1244, he conducted inquisitorial activities in various regions of Narbonne Province. ${ }^{32}$ Being one of the most experienced religious who had considerable authority and respect in the Order, Sellan and Ferrer were instrumental in organizing Papal Inquisition. ${ }^{33}$

\footnotetext{
${ }^{30}$ More on this subject in Paweł KRAS, Ad abolendam, 357-360 (here further literature).

${ }^{31}$ Yves DossAT, Les crises de l'inquisition Toulousaine au XIII' siècle (1233-1273) (Bordeaux: Imprimerie Bière, 1959), 105-131; Jörg FEUCHTER, "L'Inquisition de Toulouse. Pierre Sellan (1234 -1242), un vieillard expérimenté," in Les Inquisiteurs. Portraits de défenseurs de la foi en Languedoc (XIII ${ }^{e}-X I V^{e}$ siècles), edited by Laurent AlBARET (Toulouse: Privat, 2001), 43-55 (here further literature).

${ }^{32}$ Walter L. WAKEFIELD, "Friar Ferrier, Inquisitor," Heresis 7 (1986): 33-41; Laurent AlbARET, "L'inquisition de Carcassonne. Ferrer ou Ferrier (1229-1244), le mémoire de Montségur," in Les Inquisiteurs, 33-39. The documentation of his inquisitorial activity in the region of Lauragais in 1242-1244 has survived to this day. Jean DuVERnOY, editor, Registre de Ferrer pour le Lauragais (1242-1244) (materials archived at Centre d'Études Cathares, Carcassonne).

${ }^{33}$ The literature discussing the appointment of the first papal inquisitors for Languedoc is very extensive. Jean-Louis Biget and Laureate Albaret have recently addressed this issue in a succinct
} 
The form and functions of public penance done by heretics returning to the Church were elaborated in detail after the end of the Albigensian Crusade. After the Treaty of Paris concluded in 1229, the church authorities in Languedoc began to combat heresy systematically. The success of this fight depended on the introduction of a comprehensive penitentiary system, which not only imposed certain norms and religious attitudes, but also provided instruments to supervise their observance. ${ }^{34}$ The ritual of public penance of heretics was described in detail in the synodal statutes of Archbishop of Tarragona Peter of Albalat from 1242, the so-called Directorium of Raymond of Peyafort. The form and duration of public penance depended on the qualification of the deviation. The followers of heresy, referred to as credentes, were to do solemn penance (solemna poenitencia) in the parish church, as well as in Barcelona Cathedral. Heretics were dressed in penitential clothes, barefoot, wearing only trousers and a shirt, took part in processions to the cathedral church in Barcelona on the holidays of All Saints (1 November), the first Sunday of Advent, Christmas Day (25 December), Circumcision (1 January), Epiphany (6 January), Purification of the Blessed Virgin Mary (2 February), St. Eulalia (12 February) ${ }^{35}$ and the Annunciation of the Blessed Virgin Mary (15 March) and on all Sundays of Lent. In addition, twice a year, on the feast of the Purification of the BMV and on Palm Sunday, they had to attend a reconciliation ceremony (reconciliatio) in the

and all-embracing way. See Jean Louis BIGET, "L'inquisition en Languedoc, 1229-1329," in L'inquisizione: atti del Simposio internazionale (Città del Vaticano, 29-31 October 1998, Città del Vaticano, 2003), 41-94. Studi e Testi, 417; Laurent Albaret, "Les Prêcheurs et l'Inquisition," Cahiers de Fanjeaux 36 (2001): 319-341; IDEM, "Inquisitio Heretice Pravitatis. L'inquisition dominicaine dans le midi de la France aux XIII ${ }^{\mathrm{e}}$ et XIV ${ }^{\mathrm{e}}$ siècles ou la première inquisition pontificale," Praedicatores, Inquisitores - I. The Dominicans and the Mediaeval Inquisition. Acts of the $1^{\text {st }}$ International Seminar on the Dominicans and the Inquisition. Rome, 23-25 February 2002, edited by Wolfram HoYER (Roma: Istituto storico domenicano, 2004), 421-446. Also, see Lothar Kolmer's important studies: Ad capiendas vulpes. Die Ketzerbekämpfung in Südfrankreich in der ersten Hälfte des 13. Jahrhunderts und die Ausbildung des Inquisitionsverfahrens (Bonn: Röhrscheid, 1982) Pariser Historische Studien 19; and “....ad terrorem multorum. Die Anfänge der Inquisition in Frankreich," Die Anfänge der Inquisition im Mittelalter. Mit einem Ausblick auf das 20. Jahrhundert und einem Beitrag über religiöse Toleranz im nichtchristlichen Bereich, edited by Peter Segl (Köln-Weimar-Wien: Böhlau Verlag, 1993), 77-102. Beyreuther Historische Kolloquien, 7; see also Paweł KRAS, Ad abolendam, 166-174.

${ }^{34}$ A summary of the studies on this subject can be found in Andrew P. RoACH, "Penance and the Making of the Inquisition in Languedoc,” Journal of Ecclesiastical History 52 (2001), 409-433.

${ }^{35}$ St. Eulalia of Mérida, who suffered martyrdom in 304 during persecution under Emperor Maximian, , was the patron saint of the cathedral and the city of Barcelona. Encyklopedia katolicka, vol. 4 (Lublin: Towarzystwo Naukowe KUL, 1995), col. 1300. 
Church of Santa Maria del Mar. During this process they received public flogging, which was administered by a bishop or a designated priest. According to the previously discussed regulations, public penance, repeated each year, began on Ash Wednesday and ended on Holy Thursday. The duration of penance depended on the nature of the transgression. Credentes, as well as those who-despite an earlier reconciliation-later lent support to heretics (relapsi in fautoriam), had to do public penance for ten years. ${ }^{36}$ A shorter public penance was imposed on other categories of convicted heretics. Depending on the qualification of the deviation, in particular the frequency of contacts with the Cathar perfecti or Waldensian masters, their followers were to do public penance for seven (vehementissime suspecti), five (vehementer suspecti) or three years (fautores). ${ }^{37}$

A similar ordo of solemn public penance was included in the statutes of the Synod in Narbonne of $1243 .^{38}$ The Ordo of public penance was also included in the $13^{\text {th }}$-century manuals for papal inquisitors. The formulary of penitential document (littere de penitentiis faciendis), included in the oldest manual of this kind entitled Processus inquisitionis from 1248-1249, contains a description of penance imposed on heretics who, after revoking their errors (revocatio) and reconciling with the Church (reconciliatio), were released. Each of them had to do solemn public penance (solempnis poenitentia publica), which encompassed various religious practices. Penitents had to wear for life two yellow crosses sewn on outer clothes, one on the chest and the other on the back. The penitent heretic had to participate in all festive masses, vespers, as well as ceremonies of inquisition judgements (sermones generales) that took place in his parish church. For the period specified in the penitential document, he had to participate in church processions, following the clergy and before the faithful. At one station he had to confess publicly the sins for which he had been doing public penance. In

\footnotetext{
36 "Penitentia illorum qui relapsi sunt in fautoriam erit solepmnis ut de credentibus proximo dictum est..." Texte zur Inquisition, 58.

${ }^{37}$ Ibidem.

38 “[...] his poenitentias injungatis: videlicet ut cruces portent, quaque Dominica die inter epistolam et evangelium vestibus aliquibus denudati, prout visum fuerit pro qualitate temporis faciendum, sacerdoti parochiae suae Missam celebranti cum virgis in manu publice se praesentent, ibique recipiant disciplinam: et idem faciant in omni processione solemni. In prima etiam Dominica cujuscumque mensis, post processionem, vel Missam, visitent nudi similiter et cum virgis domos omnes, in quibus aliquando viderunt haereticos in eadem civitate seu villa, et intersint omni die Dominica Missae, ac vesperis, et sermoni generali, si fiat in villa: nisi impedimentum habuerint sine fraude." Texte zur Inquisition, 60; Joannes Dominicus MANSI, vol. 23, col. 356.
} 
the following part of the document, the sanctuaries which the heretic was to visit on penitential pilgrimages were indicated. ${ }^{39}$ Almost all subsequent forms and manuals for inquisitors included similar ordines for public penance. ${ }^{40}$ It can be found in the two most comprehensive manuals: Practica inquisitionis haereticae pravitatis by the Toulouse inquisitor Bernard Gui ${ }^{41}$ and in Directorium inquisitorum by Nicholas Eymerich, Inquisitor General for Catalonia, Aragon, Valencia and Mallorca. ${ }^{42}$ The author of Practica prescribed that heretics who do penance for the rest of their lives attend services on all Sundays and church holidays. ${ }^{43}$ During a service, the penitent heretic would stand barefoot in front of the main altar, dressed in a shirt and trousers, holding a lit candle in his hands. ${ }^{44}$ Between the readings of the Apostolic Letters and the Gospel, he was given flogging from a priest. After the service was over, the penitent participated in a procession, standing among the clergy and the faithful. At the last station of the procession he publicly confessed his sins and again received flogging. ${ }^{45}$

Medieval canon law required that all heretics who became reconciled do solemn penance in public. ${ }^{46}$ The public character of heresy (crimen publicum), which was detrimental to society as a whole, required public redress. Thanks to the fact that repentance was public, the guilt of a heretic became widely known. Therefore, the repentance had an important catechetical and preventive function. Rigorous repentance made it possible to manifest the power of the Church as well as underscoring its triumph in the fight against heresy. ${ }^{47}$ The synodal statutes of Narbonne stressed that public penance was to show "who walks in the darkness of errors and who walks in light of the true faith, who repents sincerely and who feigns his conversion." ${ }^{48}$ Public

\footnotetext{
${ }^{39}$ Processus inquisitionis, 74. For more on this, see Paweł KRAs. “...in detestationem veteris erroris. Publiczna pokuta heretyków w trzynastowiecznej Langwedocji w świetle najstarszego podręcznika inkwizycyjnego 'Processus inquisitionis' (1248-1249)." Ecclesia-cultura-potestas. Studia z dziejów kultury i społeczeństwa, edited by Paweł Kras, Agnieszka Januszek, Agnieszka Nalewajek, and Wojciech Polak (Kraków: TN Societas Vistulana, 2006), 281-293.

${ }^{40} \mathrm{John}$ H. ARNOLD, The Inquisition and Power, 51-53.

${ }^{41}$ Practica, 38.

${ }^{42}$ Manuel, 168-169.

${ }^{43}$ Practica, 38.

${ }^{44}$ Idem, 165.

${ }^{45}$ Idem, 38, 165, 166.

${ }^{46}$ Mary C. MANSFIELD, The Humilation of Sinners, 96-110.

${ }^{47}$ Ibid, 130-158; Paweł KRAS, Ad abolendam, 334-340 (here further literature).

48 “[...] saltem valeat apparere, quis in tenebris ambulet quis in luce; quis vere sit poenitens, quis ficte conversus, nec inde catholicis scandalum generetur..." Texte zur Inquisition, 61. In a similar vein, the functions of public penance were defined by Bernard Gui (Practica, 175).
} 
penance also had an important preventive function, warning the onlookers against the consequences of straying away from the Church. ${ }^{49}$ In the hands of bishops, and papal inquisitors above all, public penance became an important instrument of social control. It could take various forms, and the church judges had a lot of discretion in their choice. The form and duration of penance depended on various factors. While inflicting a punishment, the inquisition courts took into account the views of the heretic, how long he had been a member of the heretical community and the position he held in it. Attention was also paid to the age and general health of the penitent heretic. In the case of people who joined heresy in childhood, their deviation was blamed on their parents whose children were usually treated fairly mildly. Older and sick people were also treated with greater sensitivity, generally trying to adapt the form of penance to their physical abilities. ${ }^{50}$

A good insight into the form and functions of penance imposed on heretics is provided by the protocols of the Toulousan inquisitor Bernard Gui (1308-1323). ${ }^{51}$ During his term lasting nearly sixteen years, Gui imposed or changed sentences on 633 people. Almost half of them (48.7\%) were sentenced to penance in the inquisitorial prison in Toulouse. Only 16 people $(2.7 \%)$ were sentenced to penitential pilgrimages. ${ }^{52}$ In his penitential strategy, Gui insisted on strict enforcement of imposed sentences. For this reason, most prisoners had to serve penance in an inquisitorial prison, where the inquisitor could closely supervise the progress of the penance. In accordance with canon law, Gui decided on the form and duration of penance in prison. Taking into account the convict's attitude and the way in which he or she did penance, the inquisitor might extend or shorten his or her prison sentence. In the case of those whose conversion was beyond doubt, Gui allowed the penance to be continued in freedom. The visual sign of penance in progress was two brightly coloured signs of the cross on outer clothing: one on the chest and the other on the back. They had to be worn in a visible place throughout the period of penance. Failure to obey this order was regarded as a failure to do penance. ${ }^{53}$

\footnotetext{
49 James GIVEN, “A Medieval Inquisitor,” 66-67.

${ }^{50}$ Paweł KRAS, Ad abolendam, 331-333.

${ }^{51}$ Annette PALES-GOBILLIARD, editor and translator. Le livre des sentences de l'inquisteur Bernard Gui, 1308-1323, vol. 1-2 (Paris: CNRS Éditions, 2002). Sources d'histoire médiévale, 30.

${ }^{52}$ Ibid., vol. 2, p. 1646; see Paweł KRAS, Ad abolendam, 346-347, 359-360, 371-372 and the Appendix, Table no. 2, 490.

${ }^{53}$ For more on the system of penance imposed by Bernard Gui, see Jacques PAUL. "La mentalité de l'inquisiteur chez Bernard Gui." Cahiers de Fanjeaux 16 (1981): 279-316; James Given, "A Medieval Inquisitor at Work: Bernard Gui, 3 March 1308 to 19 June 1323.” Portraits of Medieval and
} 
The most severe penitential punishment was imposed on perjurers. Bernard Gui's Liber sententiarum mentions nine such sentences. ${ }^{54}$ One of them was delivered in the Toulouse Cathedral of St. Stephen on 12 April 1312, whereby penitential penalties were administered to Pons Arnaud of Pujols, who had confessed to a false accusation of his son Peter regarding the latter's support for Cathar perfecti. Bernard Gui, sentenced Arnaud to life penance in the inquisitorial prison in Toulouse. Arnaud also had to do public penance outside the prison walls. For two consecutive days, from morning to evening, he stood on the stairs in front of the entrance to St. Stephen's Cathedral. On consecutive Sundays, the same form of public penance was repeated in other places: in front of the Dominican church of St. Sernin in Toulouse and Notre Dame de la Daurade. During public penance, Pons wore a penitential robe with two red stripes sewn on it. Such acute and humiliating penance was to, as Gui argued, warn others against perjury. ${ }^{55}$

In various areas of medieval Christianity, public penance of heretics was enhanced with additional rituals, gestures, prayers and symbols (e.g. in Aragon and Castile a sanbenito was used, i.e. a yellow robe with St. Andrew's cross painted on it.) In late medieval England, heretics-Lollards took part in services in penitential costumes, holding a lit candle in their left hand and a bundle of wood on their right shoulder. After the service or liturgical procession, they left the bundles in the porch of the church. The bundles of wood held by penitents had a special didactic value because they reminded them of death penalty at the stake, which they faced should they return to heresy. ${ }^{56}$

Renaissance Living: Essays in Memory of David Herlihy, edited by Samuel Kline Cohn Jr. and Steven Epstein (Ann Arbor: University of Michigan Press, 1996), 207-232.

${ }^{54}$ Livre des sentences, vol. 2, 1646.

55 “[...] predictum Petrum Arnaldi falsum testem seu delatorem predictum ad perpetui muri carcerem acutoritate qui fungimur in hiis scriptis sentencialiter condempnamus, in quo quamdiu vixerit in pane doloris et aqua angustie faciat penitenciam salutarem, solam vitam eidem et misericordia relinquentes. Et insuper falsum testem predictum cum duabus linguis rubeis unius palmi et dimidii in longitudine et trium digitorum in latitudine ante pectore et duabus inter spatulas pendentibus, ligatis manibus elevatum in scala ante ostium hujus ecclesie cathedralis beati Stephani hodie et die crastina a summo mane usque ad nonam in loco eminenti absque aliquo velamine capitis, in tunica sine zona, ita quod a circumstantibus palam et cogoscibiliter possit videri publice conmorandum. Et quod eodem modo ponatur stet ante portas ecclesie beati Saturnini dominica subsequente et alia proxima dominica ante portam ecclesie Deaurate." Livre des sentences, vol. 1, 556.

${ }^{56}$ Norman P. TANNER. "Introduction." Heresy Trials in the Diocese of Norwich 1428-1431, edited by Norman P. Tanner (London: Offices of the Royal Historical Society, 1977), 24. Camden Fourth Series, 20. For more on the subject of penalties imposed in medieval England, see John 
This form of public penance is well illustrated by the sentence issued in 1428 in the trial of Margarita Baxter of Martham in the diocese of Norwich. Margary Baxter was one of the most zealous supporters of the Lollard doctrine, inspired by the teachings of John Wycliffe. In the literature of the subject it became a symbol of women's involvement in the activity of the first religious heterodox movement in England. Baxter not only accepted the majority of the views expressed by the Lollards (anti-clericalism, rejection of the reverence of images, pilgrimages, fasting, rituals and religious gestures), but supported their promotion. ${ }^{57}$ In the light of testimony given in 1428-1431 before the tribunal of Bishop of Norwich William Alnwick (1426-1436), Baxter appears to be a committed supporter of Lollardism, strongly criticizing Catholic clergy and rejecting most of the sacraments. Although it is impossible to regard her as a leader of local heretics, her determination to defend her views makes her an exceptional figure. ${ }^{58} \mathrm{Her}$ persistence in defending her heretical views made the penitential sentence imposed on her quite harsh. As part of public penance, Margary Baxter had to participate in processions around the parish church on four consecutive Sundays, dressed in a penitential dress. She also had to do public penance at the market square in Acle, a town east of Norfolk, near her home village. During the course of her penance she was obliged to walk in the penitential costume around the market square and to recite prescribed prayers in each corner. ${ }^{59}$ It is no coincidence that public penance was done both in the church space (parish church) and in the secular space (town square), serving to stigmatize a heretic publicly as well as deterring others from Lollardy.

Almost a hundred years later (5 May 1511), Archbishop William Warham imposed a similar form of public penance on six Kentish Lollards. On the first Saturday after the reconciliation, all penitents had to wear a badge of

A.F. Thomson. The Later Lollards (1414-1520) (Oxford: Oxford University Press, 1965), 183-190; Norman P. TANNER. "Penalties Imposed on the Kentish Lollards, 1511-1512." Lollardy and the Gentry in the Later Middle Ages, edited by Margaret Aston and Colin Richmond (Stroud-New York: Sutton Pub, St. Martin's Press, 1997), 234-240; Paweł Kras, Ad abolendam, 339 and 347.

${ }^{57}$ John A.F. ThOMSON, The Later Lollards, 116-129; Norman P. TANNER. "Introduction," throughout.

${ }^{58}$ Unlike her husband, who often travelled across Eastern England and maintained regular contacts with organized groups of Lollards, including the one in Loddon, Margary Baxter lived in isolation, rather far from Lollard centres. Shannon McScheFFrey. Gender and Heresy. Women and Men in Lollard Communities 1420-1530 (Ann Arbor: University of Pennsylvania Press, 1995), 110-114; Anne Hudson, The Premature Reformation (as per the index).

${ }^{59}$ Norwich Heresy Trials, no. 4, 41-51. 
a burning faggot on their shoulders, walk around Canterbury's town square, and participate in a solemn celebration at Canterbury Cathedral on Sunday, leading a procession in penitential robes and with real faggots on their shoulders. During mass, a group of penitents stood in front of the main altar, saying prayers and making gestures in accordance with the ordo of public penance. A similar ritual of public penance was repeated on the following Sunday in the parish church of each of the penitent Lollards. ${ }^{60}$ The uniqueness of public repentance performer by English Lollards were faggots carried by repentant heretics. After mass or the procession, they were placed in the porch of the church so that they could be used on the next day of penance. The symbolism of this ritual was clear to all of its participants. The badges of burning faggots carried on heretics' shoulders were a reminder of the punishment that awaited them should they break the reconciliatory oath and return to the previously proclaimed heretical views. ${ }^{61}$ Sometimes, as part of penance, a heretic had to stand in a public place in a special paper mitre on his head. One of the Austrian Waldensians sentenced by the inquisitor Peter Zwicker in 1398 had to stand for seven consecutive days at the pillory in the market square at Steyer, with a paper mitre on his head depicting the devil pulling the heretic by the tongue. ${ }^{62}$ The message was clear. It proved that the devil was directly responsible for the heretical errors promoted by the penitent Waldensian.

Attainment of the basic purpose of penance, i.e. the full reintegration of heretics into the Church, required the development of an efficient mechanism of supervision of penitents. Only a small proportion of heretics sentenced in inquisitorial trials did penance in prison, where they were subjected to the rhythm of prayer and asceticism under the oversight of inquisitors or bishops. Most of them did penance at large. Their penance was supervised by parish priests. In Languedoc, every heretic doing penance out of prison had to hand over to the parish priest a penitential document issued by the Inquisition Court. By virtue of this document, the pastor controlled the progress of penance, and when it was complete he informed the inquisitors about it. ${ }^{63}$ The venue for public penance was the parish church or

\footnotetext{
${ }^{60}$ Norman P. TANNER, editor. Kent Heresy Proceedings 1511-1512 (Maidstone: Kent Archeological Society, 1997), 39-40. Kent Records, 26.

${ }^{61}$ Norman P. TANNER. "Penalties," 237-238; Paweł KRAS, Ad abolendam, 339.

${ }^{62}$ Paul Peter BernARD. "Heretics in fourteenth century Austria." Mediaevalia et Humanistica 10 (1956): 62.

${ }^{63}$ For more on this, see Paweł KRAS, Ad abolendam, 323-324.
} 
cathedral, the square in front of the church, as well as the town square. In the latter case, the converted heretic either stood in a penitential robe for a certain time or had to walk around the square several times, saying prayers in each corner and accepting flogging there (fustigatio) ${ }^{64}$ When performed in a sensitive area of the urban space, public penance exposed the heretic to public view and served to stigmatize his deviations. ${ }^{65}$ Due to the public aspect of penance the whole community which the heretic was part felt responsible for its progress. All the faithful were obliged to give their "repentant brother" support and assistance. For this reason, it was forbidden to persecute heretics who were undergoing public penance. The statutes of the Synod of Bézier of 1246 threatened with excommunication, who would ridicule penitents wearing the signs of crosses. ${ }^{66}$

The penitentiary system created by papal inquisitors used a clear semiotic code. The penance of heretics took the form of public compensation for their deviation from orthodoxy. Simultaneously, however, public penance in the hands of bishops and papal inquisitors became an effective instrument of social control. Carefully staged sermones generales, during which heretics were reconciled and received punishments, was a spectacular way that the Church manifested its triumph over heresy. Judgements of condemnation against heretics who persistently upheld their views showed the power of the Church and her determination to smite the enemies of Divine Truth on the one hand, and on the other hand, through penitential punishments, the Church granted mercy to those who showed contrition and willingness to return to the unity of faith. ${ }^{67}$ Under the inquisitorial system, which was formed in the $12^{\text {th }}-13^{\text {th }}$ centuries, public penance became an important element in the fight against all forms of doctrinal deviation and disobedience to the Church. The inevitability of adjudication and enforcement of penitential penalties for heresy was to safeguard religious and social order and

\footnotetext{
${ }^{64}$ John Fines. "Heresy Trials in the Diocese of Coventry and Lichfield 1511-1512." Journal of Ecclesiastical History 14 (1963): 170; John A.F. Thomson, The Later Lollards, 231.

${ }^{65}$ Dave PostLes. "Penance and the Market Place: A Reformation Dialogue with the Medieval Church (c. 1250-c. 1600)." Journal of Ecclesiastical History 54 (2003): 441-468, especially pp. $445-447$.

${ }^{66}$ Joannes Dominicus MANSI, vol. 23, 693 (Chapter 6: Ut poenitentibus, quibus ob haeresi crimen crux est imposita, irrisio non fiat).

${ }^{67}$ Grado G. MerLo. "Il „,sermo generalis” dell'inquisitore: una sacra rappresentazione anomala." Vite di eretici e storie di frati, edited by Marina Benedetti, Grado G. Merlo, and Andrea Piazza (Milano: Biblioteca francescana, 1998), 203-220.
} 
reinforced the collective sense of justice. ${ }^{68}$ The openness or even ostentation with which the heretic repented for his deviation was a lesson in humility and at the same time a warning signal sent to others. ${ }^{69}$ The public dimension of punishment was a unique form of catechesis, enabling the promotion among the faithful what was good and salutary in the eyes of the Church, and to condemn what was evil and disastrous. In this way, public repentance became an important instrument for imposing and solidifying the system of religious and moral values proclaimed by the medieval Church.

\section{BIBLIOGRAPHY}

Arnold, John H. Inquisition and Power. Catharism and the Confessing Subject in Medieval Languedoc. Philadelphia: University of Pennsylvania Press, 2001.

Caldwell Ames, Christine. Righteous Persecution: Inquisition Dominicans and Christianity in the Middle Ages. Philadelphia: University of Pennsylvania Press, 2009.

CoHn, Norman. Europe's Inner Demons. The Demonization of Christians in Medieval Christendom. London: Pimlico, 1993.

CZERwiK, Stanisław. "Zarys dziejów pokutnej praktyki Kościoła [A historical outline of the penitential practices of the Church]." Sakrament pokuty. Teologia-Liturgia-Pismo Święte, by Alfons Skowronek, Stanisław Czerwik, Michał Czajkowski, 147-152. Katowice: Księgarnia Św. Jacka, 1980.

Kelly, John Norman Davidson. Early Christian Doctrines. London: Adam \& Charles Black, 1977.

LE Goff, Jacques. Narodziny czyśćca [The birth of Purgatory]. Translated by Krzysztof Kocjan. Warszawa: Państwowy Instytut Wydawniczy, 1997.

Mansfield, Mary C. The Humiliation of Sinners. Public Penance in Thirteenth Century France. Ithaca-London: Cornell University Press, 1995.

Merlo, Grado G. "Membra diaboli, demoni ed eretici medievali." Nuova Rivista Storica 72, nos. 5-6 (1988): 583-598.

Michaud-Quantin, Pierre. Sommes de casuistiques et manuels de confession au Moyen Age (XII-XVI siècle). Louvain: Libraire Dominicine, 1962.

Patschovsky, Alexander. "Der Ketzer als Teufeldiener." Papstum, Kirche und Recht im Mittelalter. Festschrift H. Fuhrmann zum 65. Geburtstag, edited by Hubert Mordek, 317334. Tübingen: Max Niemeyer Verlag, 1991.

RoACH, Andrew P. "Penance and the Making of the Inquisition in Languedoc." Journal of Ecclesiastical History 52 (2001): 409-433.

\footnotetext{
${ }^{68}$ James GIVEN, “A Medieval Inquisitor,” 66-67.

${ }^{69}$ David Garland, Punishment and Modern Society: A Study in Social Theory (Oxford: Clarendon, 1990), 18-22.
} 


\title{
PUBLIC PENANCE OF HERETICS: ITS FORMS AND FUNCTIONS
}

\begin{abstract}
Summary
The article discusses the origins of public penance for heresy in the early Christian tradition as well as examining its application in the penitential practice of the medieval Church. It demonstrates how public penance for mortal sins, which took shape in Late Antiquity, was later adopted and developed within the system of medieval Inquisition. In the medieval collections of canon law, heresy was qualified as a religious crime which required special public penance. Following the guidelines set up in the ancient Church, any heretic who declared his or her intention to renounce their wrongs was to be interrogated by a bishop, who would grant them absolution of sins and prescribed due penance. An important aspect of penance for heresy was public solemn penitence, which took place on Sundays and feast days and included a number of rituals. The penitent heretic had to appear in a special garment with his or her hair cut off and barefoot. The ritual of solemn public penitence for mortal sins was formed in Late Antiquity and as such was later incorporated into medieval pontificals.

The rise of medieval Inquisition, which was used as an efficient weapon against popular heresy, stimulated the development of penitential discipline for heretics. Papal Inquisitors, who came to be appointed as extraordinary judges in heresy trials since the 1230s, were particularly inventive in the way how public penance might be employed to fight heretics. Medieval registers of heresy trials, carried out by papal inquisitors and bishops, are still the main source of information about penalties imposed on heretics who were sentenced for their errors. The public announcement of a sentence and penalty was the final act of the inquisitorial procedure. The penitential document (littera penitentialis), which was first read publicly and later handed over to the penitent heretic, listed various forms of penitence which he had to fulfil. In the inquisitorial strategy of penance, which started to be used in the first half of the thirteenth century, a solemn public penitence of heretics became commonplace. The inquisitorial registers and manuals for inquisitors described in detail the ritual of public penance and its functions. The penance imposed on heretics offered them a chance to repent publicly for their public crimes and to give satisfaction to society which had been disturbed by their deeds. That is why solemn public penance usually took place in a cathedral or central market square on feast days to be attended and witnessed by the local community. Through his special appearance and penitential garment with two penitential crosses, the heretic was highly visible and could not be anonymous. The whole society was responsible for supervising the penance of heretics and controlling their religious and moral conduct. Any act of religious transgression or misconduct was to be reported to the ecclesiastical authorities. Of course, public penitence was aimed at teaching a lesson to all the faithful and preventing them from falling into heresy.
\end{abstract}

Key words: heresy; Inquisition; rituals; penance.

Translated by Tomasz Patkowski

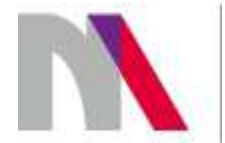

The preparation of the English version of Roczniki Humanistyczne (Annals of Arts) and its publication in electronic databases was financed under contract no. 836/P-DUN/2018 from the resources of the Minister of Science and Higher Education for the popularization of science. 